\title{
The Problematic of Disaster Management in Nigeria: A Study of Bayelsa State
}

Ogochukwu Harrison Amede ${ }^{1}$, Kelly Bryan Ovie Ejumudo ${ }^{*}$

${ }^{1}$ Department of Curriculum and Instructional Technology, University of Benin, Benin City, Nigeria

2 Department of Political Science, Novena University, Ogume, Nigeria

${ }^{*}$ Corresponding Email: profkellynovena@yahoo.com

Abstract: The study examined the problematic of disaster management in Nigeria using Bayelsa State as a case study. Four null hypotheses were raised and tested at 0.05 level of significant. The study adopted the descriptive survey design and sample sizes of 300 adults were drawn from fifteen (15) affected communities in Bayelsa State. The instrument used for data collection was disaster management questionnaire and the data were analyzed using chi-square. The finding of the study revealed that there is a significant relationship between poor integrated policy and action plan as well as weak institutional capacity and collaboration of disaster management agencies and effectiveness of disaster management in Bayelsa State. The study clearly showed that there is a significant relationship between poor commitment and piece-meal approach by the multi-layered levels of government as well as poor stakeholders' participation and synergy and effectiveness of disaster management in Bayelsa State. The study recommended among others that long-term monitoring and surveillance mechanism; continuous provision of infrastructure for the host communities by prospecting oil companies; adequate funding by governmental and non-governmental and the development of national oil spill contingency plan should be adopted and deployed with an eye to guaranteeing sustainable development of the environment in the region.

Keywords: Problematic; Disaster; Management; Bayelsa State; Nigeria 


\section{A. Introduction}

Disasters which can be natural or human have become a global concern in such a way and manner that it has engaged the attention of local and international institutions and agencies, national, state and local governments, private sector organizations, the academia, the media and prominent individuals. Disasters that include floods, windstorms, epidemic, oil spillage, fire outbreak, communal clashes and insurgency militant attacks and killings have also been more re-occurring and widespread in the face of the vulnerability of the vast majority of the affected communities and people.

In Nigeria, there has been a remarkable and significant increase in the occurrence and number of disasters. In fact, Nigeria has over the years experienced more floods and strong windstorms as well as epidemics and twenty-three states were affected by floods in 2010 with 1555 killed and 258,044 displaced. ${ }^{1}$ This trend is in tandem with the United Nations (UN) report that documented disasters have increased from 200 yearly to 400 yearly across the globe in the past two decades. These visible developments may have largely necessitated the establishment of Emergency Management Agencies Abuja and in most of the states in Nigeria. All the same, disaster incidents have assumed an ever-increasing and worrisome level.

Disasters have been recognized and accepted as inevitable occurrences in both rural communities and urban centers. ${ }^{2}$ Sundry types of disaster have also left their toll and manifold effects on the socio-economic lives of different categories of rural and urban dwellers, particularly the more vulnerable and highly marginalized. In fact, the level of vulnerability to natural and anthropogenic hazards and effects of disasters is unacceptably high in Nigeria. For instance, floods and wind-storms appear to be very devastating to local community dwellers that rely largely on nature and the environmental that are very susceptible to the impacts of various incidents of disasters. Many of them build their houses and plant their crops in floodprone areas due to their poor socio-economic status and low-level awareness of the inherent hazards and concomitant threats to their livelihoods and human existence.

1 NEMA (2017). Floods warning preparedness and safety. Emergency Management Australia. (EMA).

2 Kelly Bryan Ovie Ejumudo, (2015). Managing the development/environment dilemma: The global challenge. Journal of Development Alternatives and Area Studies, 31 (2), 18 43.

36 Indonesian Journal of Advocacy and Legal Services, Vol. 3 No. 1 (2021) 
There are equally many cases of people who built structurally defective houses that are inadequate and cannot cope with or withstand flood and windstorm. Worse still, many other community dwellers or inhabitants are caught up in the dastardly acts occasioned by accidental or humaninduced pipeline explosion, oil spillage, as well as violent community clashes and insurgency militant related killings. All of the above disaster incidents have not only threatened human existence, they equally have grave implications including socio-economic displacement or dislocation for the affected persons and deprivation of the different levels of government from valuable sources of revenue needed for development.

In view of the preponderance of the occurrence and the accompanying cross-cutting effects of disasters in Nigeria, disaster management has become an on-going concern with different measures put in place expectedly to tackle the perennial hydra-headed problems of various types of disaster. For instance, National, State and Local Emergency Management Agencies have been established in the Federal Capital Territory and in most of the states in Nigeria. Regrettably however, most of the state and local government agencies are poorly equipped and largely inadequately functional such that they lack the capacity to contribute to the achievement of the multiple tasks of disaster prevention, mitigation and quick response that are central to effective disaster management in Nigeria.

Programmes like the Grassroots Emergency Management Volunteer Corps (GEVC) and the Emergency Management Vanguards (EMV) introduced by the National Emergency Management Agency (NEMA) in 2008 and 2010 respectively are part of efforts supposedly aimed at training volunteers in disaster management skills to enable them play important roles in disaster risk reduction in various community. Other risk reduction strategies in Nigeria include the introduction of policies, regulations and procedures meant to control design standards, building codes, health and safety regulations and urban planning. The National Emergency Management Agency (NEMA) that has the mandate to collect emergency relief supply from local and foreign sources including international and nongovernmental agencies has also been somehow in the forefront in making relief items available to victims of disasters including floods and co-ordinate efforts of some other government agencies.

Despite the measures put in place and the sundry efforts made by disaster management agencies in Nigeria, the efficacy of disaster management has over the years been constrained by different factors including poor integrated policy and action plan, poor institutional capacity and collaboration by disaster management agencies, poor commitment and 
piece-meal approach by the multi-layered levels of government, weak stakeholder participation and synergy (including community-based organizations) and poverty-related vulnerability of communities and dwellers.

\section{Statement of the Problem}

Despite the significant increase in the occurrence and the accompanying cross-cutting effects of disasters in Nigeria as well as the seemingly growing concern with disaster management as evident in the different measures put in place expectedly to tackle the perennial hydraheaded problem, the effectiveness of disaster management efforts and action programmes appears to be constrained by various factors such as poor integrated policy and action plan, weak institutional capacity and collaboration by multi-layered levels of government, poor commitment and piece-meal approach by government as well as poor stakeholders' participation and synergy. This study therefore investigates the problematic of disaster management in Nigeria, using Bayelsa State as a case study.

\section{Objectives of the Study}

The general objective of the study is to examine the problematic of disaster management in Nigeria, using Bayelsa State as a case study, while the specific objectives are to:

1. Assess the impact of poor integrated policy and action plan on the effectiveness of disaster management in Bayelsa State.

2. Investigate the influence of weak institutional capacity and collaboration by disaster of multi-layered levels of government on the effectiveness of disaster management in Bayelsa State.

3. Examine the impact of poor commitment and piece-meal approach (non-holistic reactive) of multi-layered levels of government on the effectiveness of disaster management in Bayelsa State.

4. Examine the influence of stakeholders' participation and synergy on the effectiveness of disaster management in Bayelsa State.

\section{Hypotheses of the Study}

1. There is no significant relationship between poor integrated policy and action plan and effectiveness of disaster management in Bayelsa State. 
2. There is no significant relationship between weak institutional capacity and collaboration by disaster of multi-layered levels of government on the effectiveness of disaster management in Bayelsa State.

3. There is no significant relationship between poor commitment and piece-meal approach (non-holistic reactive) of multi-layered levels of government and the effectiveness of disaster management in Bayelsa State.

4. There is no significant relationship between stakeholders' participation and synergy and the effectiveness of disaster management in Bayelsa State.

\section{Empirical Studies on Disaster}

Osumgborogwu, Okoro, and Oduaro assessed social effects of crude oil exploration and extraction activities in some selected communities in Egbema of Imo State. The findings of the study showed that social activities in the community have not been affected by crude oil production and recommended that further research be carried out to assess security effects of crude oil production. ${ }^{3}$ Abosede examined the effect of oil exploitation on the socioeconomic life of the Ilaje-Ugbo people of Ondo State, Nigeria. The findings of the study revealed that oil exploitation, through environmental degradation, depleted the fishing and farming output, resulting in the subsequent loss of income base, thereby accentuating poverty, which in turn created divisive tendencies leading to endemic social conflict. ${ }^{4}$

Nkwunonwo also investigated flooding and flood risk reduction in Nigeria and discovered that flooding which has been very damaging for Nigeria has worsened recently due to a number of factors including rapid population growth, urbanization, poor urban planning and climate change especially in increased frequency and intensity of rainfall. ${ }^{5}$ In a similar context, Oladokun explored flood risk management in Nigeria and reviewed the challenges and opportunities. The findings of the study showed that absence of integrated FRM systems, lack of interagency coordination,

3 Osumgborogwu, I. E., Okoro, F. C. and Oduaro, I. J. (2018). Social effects of crude oil exploration and extraction activities in some selected communities in Egbema of Imo State. Asian Research Journal of Arts and Social Science, 3 (2), 1-7.

4 Abosede, B. (2017). Effect of oil exploitation on the socio-economic life of the Ilaje-Ugbo people of Ondo State, Nigeria. Journal of Sustainable Development in Africa, 12 (5), 6184.

5 Nkwunonwo, U. C. (2016). Flooding and Flood Risk Reduction in Nigeria: Cardinal Gaps. Journal of Geography and Natural Disaster, 5 (1), 1-12. 
substandard and weak infrastructures, inadequate drainage network, high urban poverty, low level literacy, cultural barriers and weak institutions characterize current FRM practices ${ }^{6}$, while Emeribeole investigated flood disaster management in Owerri metropolis of Imo State and the results obtained in this study indicated that dumpsites within the river channel as well as structural development within the floodplain and high amount of rainfall are the major causes of inundation in the city, especially in the wet season. ${ }^{7}$

Iyorakpo examined the impact of rapid urbanization on environmental quality in Yenagoa metropolis of Bayelsa State Nigeria and the results of the findings showed that there are serious abuses on the environment which resulted to poor environmental quality. ${ }^{8}$ Equally, Otomofa, Okafor and Obienusi evaluated the impacts of flooding on socio-economic activities in Oleh, Isoko South Local Government Area of Delta State and the study revealed that flooding has significant relationship with socio-economic activities in Oleh and loss of portable water and agricultural products were revealed as some of the negative impacts of flooding in the study area. ${ }^{9}$ In a similar vein, Tonbra investigated the socio-cultural effects of flooding in Bayelsa State using Southern Ijaw Local Government Area as a case study. The study revealed that the people of Southern Ijaw were devastated, displaced and rendered homeless by the 2012 flooding and their socio-cultural heritage was severely affected. ${ }^{10}$

Ibimilua examined the types, spatial distribution, causes and consequences of environmental challenges in Nigeria and the findings revealed that different types of disaster including flooding has persisted largely due to poor disaster prevention, reduction, mitigation and

6 Oladokun, V. (2016). Flood risk management in Nigeria: A review of the challenges and opportunities. Article (PDF Available) - January 2016 with 72 Reads DOI: 10.2495/SAFE-V6-N3-485-497 David Proverb

7 Emeribeole, A. C. (2015). Managing flood disaster in Nigerian cities: Issues and strategies toward meeting the challenges in the modern world: A case study of Owerri metropolis. 17-21 May 2015, 1-16.

8 Iyorakpo, J. (2015). The impact of rapid urbanization on environmental quality in Yenagoa metropolis of Bayelsa State Nigeria. European Scientific Journal, 11(23), 255268.

9 Otomofa, J. O., Okafor, B. N. and Obienusi, B. N. (2015). Evaluation of the Impacts of Flooding On Socio-Economic Activities in Oleh, Isoko South Local Government Area, Delta State Journal of Environment and Earth Science, 5 (18), 155-171.

10 Tonbra, R. O. (2014). The socio-cultural effects of flooding in Bayelsa State: A case study of Southern Ijaw Local Government Area. Journal of Social Sciences, 5 (27), 1-8.

40 Indonesian Journal of Advocacy and Legal Services, Vol. 3 No. 1 (2021) 
management strategies. ${ }^{11}$ Sajini assessed socio-economic problems of oil exploration and exploitation in Nigeria's Niger Delta since the 1970s and the results from the study indicated that there exist a paradox in the context of the fact that oil from Niger Delta has generated massive economic and social transformations of many parts of the country on the one hand and it has resulted into unparalleled damage to the Niger Delta environment on the other hand ${ }^{12}$, while Obinna examined the impact of incidents of flooding in Nigeria Obinna with a view to ascertaining the level of implementation of government policy aimed at mitigating the effects of natural disaster in 2012 and the findings of the study showed that the efficacy of disaster management efforts by ministries and agencies have been constrained by external factors like funding and lack of trained manpower and personnel..$^{13}$

Olujimi, Adebayo, and Sogbon assessed environmental implications of oil exploitation in the coastal region of Ondo State, Nigeria and discovered that large-scale environmental pollution and degradation of agricultural land which serves as source of income for the people coupled with social unrest arising from unpaid claims of compensation and lack of concern for the people in the exploration area were worsened mainly as a result of over-exploitation of natural resources, poverty as well as poor planning and management strategies by government agencies. ${ }^{14}$ Olusiyi equally examined the effects of oil spillage on the socio-economic activities of the people and the environment in some communities in the Niger Delta and the results of the study pointed the fact that there is a strong relationship between the volume of oil spilled and the environment with serious implications for the soil, water and the socio-economic activities of the people. ${ }^{15}$

Olorunfemi and Raheem examined the concept of disaster and its management in the light of sustainable development with particular reference to Nigeria and discovered that while hazards and disasters possess

11 Ibimilua, A. F. (2014). Environmental challenges in Nigeria: Typology, spatial distribution, repercussions and way forward. American International Journal of Social Science, 3 (2), 246-253

12 Sajini, F. I. (2013). Socio-economic problems of oil exploration and exploitation in Nigeria's Niger Delta.Journal of Energy Technologies and Policy, 3 (1),76-80.

13 Obinna, N. (2012). Flood and government policy response in the Niger Delta. Journal of Political Science and Leadership Research, 2 (2), 1-10.

14 Olujimi, J. A. B., Adebayo, E. A and Sogbon, O. (2011). Environmental implications of oil exploration and exploitation in the coastal region of Ondo State Journal of Geography and Regional Planning, 4(3), 110-121.

15 Olusiyi, I. (2009). The effects of oil spillage on the socio-economic activities of the people and the environment in some communities in the Niger Delta. Journal of Integrative Environmental Science, 6 (1), 7-23. 
anthropogenic origins, their consequences are felt on both human and the physical environments largely due to poverty and environmental misuse ${ }^{16}$, while Asia, Jegede, Jegede, Ize-Iyamu and Akpasubi investigated the effects of petroleum exploration and production operations on the heavy metals contents of soil and groundwater in the Niger Delta and the results showed that the amount of lead present in the soil ranges from $3.40-99.40 \mathrm{mg} / \mathrm{kg} .{ }^{17}$

\section{B. Method}

This research endeavour employed descriptive survey design. The utilitarian value of this design to this study is evident in the fact that its enabled the researcher to use questionnaire to obtain information on the variables under study from the sample that was drawn from the population. The sample of the study consists of three hundred (300) adults. The three hundred adults were selected from six towns amongst the towns in Bayelsa State that have experienced flood and oil spillage. The six towns and three hundred adults were selected using purposive sampling technique. The choice of purposive sampling technique was predicated on the fact that the selected towns and adults were accessible to the researcher.

The instrument that was used for data collection is the disaster management questionnaire which contained twenty (20) items and assisted the researcher to spread the questions/items across the independent and intervening variables. All the research hypotheses were tested for significant difference at 0.05 level of significance using Chi-Square.

\section{Presentation and Discussion of Results}

The results of the data analysis are presented in accordance with the research hypotheses.

\section{Hypothesis 1 (Ho1)}

There is no significant relationship between the poor integrated policy and action plan and effectiveness of disaster management in Bayelsa State.

16 Olorunfemi, F. B. and Raheem U. A. (2008). Sustainable disaster risk reduction in Nigeria: Lessons for developing countries. African Research Review, 2(2), 187-287

17 Asia, I., S. Jegede, D. Jegede, Ize-Iyamu, O. and Akpasubi, E. (2007). The effects of petroleum exploration and production operations on the heavy metals contents of soil and groundwater in the Niger Delta. American Journal of Environmental Protection, 1(4), 271275 . 
Table 1. Chi-square analysis of questionnaire for the relationship between poor integrated policy and action plan and effectiveness of disaster management in Bayelsa State

\begin{tabular}{|c|c|c|c|c|c|c|c|}
\hline Items & SA/A & SD/D & Total & Df & $\mathrm{X}^{2}-\mathrm{Cal}$ & $\mathrm{X}^{2}-\mathrm{Cri}$ & Decision \\
\hline 1 & 68 & 32 & 290 & \multirow{5}{*}{3} & \multirow{5}{*}{42.83} & \multirow{5}{*}{7.82} & \multirow{5}{*}{$\begin{array}{l}\mathrm{Ho}_{1} \text { is } \\
\text { Rejected }\end{array}$} \\
\hline 2 & 34 & 66 & 290 & & & & \\
\hline 3 & 68 & 32 & 290 & & & & \\
\hline 4 & 70 & 30 & 290 & & & & \\
\hline 5 & 62 & 38 & 290 & & & & \\
\hline
\end{tabular}

\section{Source: Field Work, 2019}

$$
\mathrm{P}>0.05
$$

In table 1 above, with alpha level of 0.05 , the degree of freedom (DF) of 3 , the critical value is 7.82 while calculated value is 42.83 . Since the calculated value is greater than the critical value, the null hypothesis is therefore rejected. This shows that there is a significant relationship between the poor integrated policy and action plan and effectiveness of disaster management in Bayelsa State.

\section{Hypothesis 2 (Ho2)}

There is no significant relationship between weak institutional capacity and collaboration of disaster management agencies and effectiveness of disaster management in Bayelsa State.

Table 2. Chi-square analysis of questionnaire for the relationship between weak institutional capacity and collaboration of disaster management agencies and effectiveness of disaster management in Bayelsa State

\begin{tabular}{|c|c|c|c|c|c|c|c|}
\hline Items & SA/A & SD/D & Total & Df & $\mathrm{X}^{2}-\mathrm{Cal}$ & $\mathrm{X}^{2}-\mathrm{Cri}$ & Decision \\
\hline 1 & 62 & 38 & 290 & \multirow{5}{*}{3} & \multirow{5}{*}{20.81} & \multirow{5}{*}{7.82} & \multirow{5}{*}{$\begin{array}{l}\mathrm{Ho}_{2} \text { is } \\
\text { Rejected }\end{array}$} \\
\hline 2 & 57 & 43 & 290 & & & & \\
\hline 3 & 62 & 38 & 290 & & & & \\
\hline 4 & 63 & 37 & 290 & & & & \\
\hline 5 & 60 & 40 & 290 & & & & \\
\hline
\end{tabular}

Source: Field Work, 2019

$\mathrm{P}>0.05$

Table 2 above show the alpha level of 0.05 , degree of freedom (DF) of 3 and the critical value is 7.82 while the calculated value is 20.82 . Since the calculated value 20.82 is greater than the critical value 7.82 , the null hypothesis is therefore rejected. This shows that there is a significant relationship between weak institutional capacity and collaboration of disaster management agencies and effectiveness of disaster management in Bayelsa State. 


\section{Hypothesis 3 (Ho3)}

There is no significant relationship between poor commitment and piece-meal approach by the multi-layered levels of government and effectiveness of disaster management in Bayelsa State.

Table 3. Chi-square analysis of questionnaire for the relationship between poor commitment and piece-meal approach by the multi-

layered levels of government and effectiveness of disaster management in Bayelsa State

\begin{tabular}{|c|c|c|c|c|c|c|c|}
\hline Items & SA/A & SD/D & Total & Df & $\mathrm{X}^{2}-\mathrm{Cal}$ & $\mathrm{X}^{2}-\mathrm{Cri}$ & Decision \\
\hline 1 & 60 & 40 & 290 & \multirow{5}{*}{3} & \multirow{5}{*}{27.14} & \multirow{5}{*}{7.82} & \multirow{5}{*}{$\begin{array}{l}\mathrm{Ho}_{3} \text { is } \\
\text { Rejected }\end{array}$} \\
\hline 2 & 66 & 34 & 290 & & & & \\
\hline 3 & 65 & 35 & 290 & & & & \\
\hline 4 & 65 & 35 & 290 & & & & \\
\hline 5 & 63 & 37 & 290 & & & & \\
\hline
\end{tabular}

Source: Field Work, 2019

$\mathrm{P}>0.05$

In table 3 above, with alpha level of 0.05 , the degree of freedom (DF) of 3 , the critical value is 7.82 while calculated value is 25.97 . Since the calculated value is greater than the critical value, the null hypothesis is therefore rejected. This implies that there is a significant relationship between poor commitment and piece-meal approach by the multi-layered levels of government and effectiveness of disaster management in Bayelsa State.

4. Hypothesis 4 (Ho4)

There is no significant relationship between poor stakeholders' participation and synergy and effectiveness of disaster management.

Table 4. Chi-square analysis of questionnaire for the relationship

between poor stakeholders' participation and synergy and effectiveness of disaster management in Bayelsa State

\begin{tabular}{|c|c|c|c|c|c|c|c|}
\hline Items & SA/A & SD/D & Total & Df & $\mathrm{X}^{2}-\mathrm{Cal}$ & $\mathrm{X}^{2}-\mathrm{Cri}$ & Decision \\
\hline 1 & 65 & 35 & 290 & \multirow{5}{*}{3} & \multirow{5}{*}{46.59} & \multirow{5}{*}{7.82} & \multirow{5}{*}{$\begin{array}{l}\mathrm{Ho}_{4} \\
\text { Rejected }\end{array}$} \\
\hline 2 & 60 & 40 & 290 & & & & \\
\hline 3 & 64 & 36 & 290 & & & & \\
\hline 4 & 66 & 34 & 290 & & & & \\
\hline 5 & 69 & 31 & 290 & & & & \\
\hline
\end{tabular}

\section{Source: Field Work, $2019 \quad \mathrm{P}>0.05$}

Table 4 shows the alpha level of 0.05 , the degree of freedom (DF) of 3 , the critical value 7.82 while calculated value 46.59 . Since the calculated value 
is greater than the critical value, the null hypothesis is therefore rejected. This shows that there is a significant relationship between poor stakeholders' participation and synergy and effectiveness of disaster management in Bayelsa State.

\section{Discussion of Findings}

The study showed that there is a significant relationship between poor integrated policy and action plan and effectiveness of disaster management in Bayelsa State. The above finding is evident in the fact that there is a gap between the internal and external environment and the various agencies and stakeholders that are saddled with the responsibilities of disaster management which have culminated in poor environmental quality. This finding also gives credence to Oladokun who investigated flood risk management in Nigeria and found out that there are no integrated flood risk management (FRM) systems, inter-agency coordination coupled with substandard and weak infrastructures, inadequate drainage network, high urban poverty, low level literacy; cultural barriers as well as weak institutional policy and action plan. ${ }^{18}$

The finding of the study revealed that there is a significant relationship between weak institutional capacity and collaboration of disaster management agencies and effectiveness of disaster management in Bayelsa State. One plausible explanation for this finding is that because of poor institutional capacity and collaboration on disaster management, there are serious abuses and contraventions on the environment as well as unplanned structures and haphazard disposition of refuse which resulted to environmental degradation and poor environmental quality. ${ }^{19}$

The study equally showed that there is a significant relationship between poor commitment and piece-meal approach by the multi-layered levels of government and effectiveness of disaster management in Bayelsa State. It is instructive to note that this finding is patently evident owing to the fact that because of poor commitment and piece-meal approach by multilayered levels of government to disaster management, there are rising cases

18 Oladokun, V. (2016). Flood risk management in Nigeria: A review of the challenges and opportunities. Article (PDF Available) · January 2016 with 72 Reads DOI: 10.2495/SAFE-V6-N3-485-497 David Proverb

19 Iyorakpo, J. (2015). The impact of rapid urbanization on environmental quality in Yenagoa metropolis of Bayelsa State Nigeria. European Scientific Journal, 11(23), 255268. 
of flood and other disaster associated problems in Nigeria. The finding is additionally in congruence with Nkwunonwo, Whitworth and Baily who articulated that the poor commitment of government to disaster management is as a result of near absence of robust and scientific approaches like flood modeling and vulnerability assessment to flood risk reduction in Nigeria. ${ }^{20}$

The study further revealed that there is a significant relationship between poor stakeholders' participation and synergy and effectiveness of disaster management in Bayelsa State. Premised on the above finding, it can be deduced that there is no adequate collaboration, teamwork and synergy amongst the stakeholders and various agencies that were established and have the statutory function and responsibility to prevent and manage flood and other problems that are associated with disaster in Nigeria. This finding is in consonance with Obinna who examined the impact of incidents of flooding in Nigeria with a view to ascertaining the level of implementation of government policy aimed at mitigating the effect of the natural disaster in $2012 .{ }^{21}$

\section{E. Conclusion}

Based on the above findings of the study, the following conclusions were drawn. Firstly, since there is a significant relationship between poor integrated policy and action plan and effectiveness of disaster management in Bayelsa State, it is concluded that there is a gap between the internal and external environment as well as the various agencies and stakeholders that are saddled with the responsibilities of disaster management which have culminated in poor environmental quality. Secondly, as far as there is a significant relationship between weak institutional capacity and collaboration of disaster management agencies and effectiveness of disaster management in Bayelsa State, it can be inferred that poor institutional capacity and collaboration on disaster management, abuses and contraventions on the environment as well as unplanned structures and haphazard disposition of refuse have affected disaster management in Bayelsa State. In a similar vein, since there is a significant relationship between poor commitment and piece-meal approach by the multi-layered levels of government and effectiveness of disaster management in Bayelsa

20 Nkwunonwo, U. C. (2016). Flooding and Flood Risk Reduction in Nigeria: Cardinal Gaps. Journal of Geography and Natural Disaster, 5 (1), 1-12.

21 Obinna, N. (2012). Flood and government policy response in the Niger Delta. Journal of Political Science and Leadership Research, 2 (2), 1-10.

46 Indonesian Journal of Advocacy and Legal Services, Vol. 3 No. 1 (2021) 
State, it is logical to state that poor commitment and piece-meal approach by multi-layered levels of government on disaster management have constrained effective disaster management in Bayelsa State. In like manner, in so far as there is a significant relationship between poor stakeholders' participation and synergy and effectiveness of disaster management in Bayelsa State, it can be deduced that there is no collaboration, teamwork and synergy amongst the stakeholders and various agencies that were established and have the statutory function and responsibility to prevent and manage flood and other problems that are associated with disaster in Bayelsa State.

\section{F. Recommendation}

In the light of the findings and conclusion of the study, the following recommendations are made:

1. The multi-layered levels of the government should formulate and genuinely implement policies that will mitigate the effects of disaster on the health, economic and livelihood status of the people in Bayelsa State.

2. Individual, corporate bodies and government should allocate adequate fund to disaster management bodies for proper planning of the area and community-based flood warning system should be developed so as to create awareness and preparedness of the inhabitants of the Niger Delta against severe flooding and any other disaster.

3. Long-term monitoring and surveillance mechanism; continuous provision of infrastructure for the host communities by prospecting oil companies; and the development of national oil spill contingency plan among others, should be adopted and deployed with an eye to guaranteeing sustainable development of the environment in the region.

\section{G. Acknowledgments}

Authors express the thankfulness to all parties involved on this research and to all faculty member and research team from Novena University and University of Benin of their support and helps.

\section{H. Declaration of Conflicting Interests}

The authors state that there is no potential conflict of interest in the research, authorship, and/or publication of this article. 


\section{Funding}

None

\section{J. References}

Abosede, B. (2017). Effect of oil exploitation on the socio-economic life of the Ilaje-Ugbo people of Ondo State, Nigeria. Journal of Sustainable Development in Africa, 12 (5), 61-84.

Asia, I., S. Jegede, D. Jegede, Ize-Iyamu, O. and Akpasubi, E. (2007). The effects of petroleum exploration and production operations on the heavy metals contents of soil and groundwater in the Niger Delta. American Journal of Environmental Protection, 1(4), 271-275.

Ejumudo, K. B. O. (2015). Managing the development/environment dilemma: The global challenge. Journal of Development Alternatives and Area Studies, 31 (2), 18-43.

Emeribeole, A. C. (2015). Managing flood disaster in Nigerian cities: Issues and strategies toward meeting the challenges in the modern world: A case study of Owerri metropolis. 17-21 May 2015, 1-16.

Ibimilua, A. F. (2014). Environmental challenges in Nigeria: Typology, spatial distribution, repercussions and way forward. American International Journal of Social Science, 3 (2), 246-253

Iyorakpo, J. (2015). The impact of rapid urbanization on environmental quality in Yenagoa metropolis of Bayelsa State Nigeria. European Scientific Journal, 11(23), 255-268

NEMA (2017). Floods warning preparedness and safety. Emergency Management Australia. (EMA).

Nkwunonwo, U. C. (2016). Flooding and Flood Risk Reduction in Nigeria: Cardinal Gaps. Journal of Geography and Natural Disaster, 5 (1), 112.

Obinna, N. (2012). Flood and government policy response in the Niger Delta. Journal of Political Science and Leadership Research, 2 (2), 1-10.

Oladokun, V. (2016). Flood risk management in Nigeria: A review of the challenges and opportunities. Article (PDF Available) · January 2016 with 72 Reads DOI: 10.2495/SAFE-V6-N3-485-497 David Proverb

Olorunfemi, F. B. and Raheem U. A. (2008). Sustainable disaster risk reduction in Nigeria: Lessons for developing countries. African Research Review, 2(2), 187-287

Olujimi, J. A. B., Adebayo, E. A and Sogbon, O. (2011). Environmental implications of oil exploration and exploitation in the coastal region of Ondo State Journal of Geography and Regional Planning, 4(3), 110121. 
Olusiyi, I. (2009). The effects of oil spillage on the socio-economic activities of the people and the environment in some communities in the Niger Delta. Journal of Integrative Environmental Science, 6 (1), 7-23.

Osumgborogwu, I. E., Okoro, F. C. and Oduaro, I. J. (2018). Social effects of crude oil exploration and extraction activities in some selected communities in Egbema of Imo State. Asian Research Journal of Arts and Social Science, 3 (2), 1-7.

Otomofa, J. O., Okafor, B. N. and Obienusi, B. N. (2015). Evaluation of the Impacts of Flooding On Socio-Economic Activities in Oleh, Isoko South Local Government Area, Delta State Journal of Environment and Earth Science, 5 (18), 155-171.

Sajini, F. I. (2013). Socio-economic problems of oil exploration and exploitation in Nigeria's Niger Delta.Journal of Energy Technologies and Policy, 3 (1),76-80.

Tonbra, R. O. (2014). The socio-cultural effects of flooding in Bayelsa State: A case study of Southern Ijaw Local Government Area. Journal of Social Sciences, 5 (27), 1-8. 
O. H. Amede \& K. B. O. Ejumudo

\section{ABOUT AUTHORS}

Ogochukwu Harrison Amede, is a Faculty Member at the Department of Curriculum and Instructional Technology, University of Benin, Benin City, Nigeria. One of his research publications is concerning Oil Production and The Problematic of Water Pollution in The Niger Delta: A Study of Selected Communities in Bayelsa State (Research in Social Change, 2019)

Prof. Kelly Bryan Ovie Ejumudo, is a senior lecturer at the Department of Political Science, Novena University, Nigeria. He teaches undergraduate and postgraduate students at the university. His core areas are public administration and environmental and development studies. Some of his publications such as Institutional Decay and Religious Proliferation in Nigeria: A Critical Examination (Research on Humanities and Social Sciences, 2013), Gender Equality and Women Empowerment in Nigeria: The Desirability and Inevitability of a Pragmatic Approach (Developing County Studies, 2013), and Youth Restiveness in the Niger Delta: A Critical Discourse (SAGE Open, 2014). 